\title{
INTEGRATION OF INNOVATION THROUGH ANALYTICAL HIERARCHY PROCESS (AHP) IN PROJECT MANAGEMENT AND PLANNING
}

\author{
Murat GUNDUZ*, Mohammed ALFAR \\ Department of Civil Engineering, Qatar University, P.O. Box: 2713 Doha, Qatar \\ Received 7 February 2018; accepted 25 November 2018
}

\begin{abstract}
This paper examines the concept of innovation management in the construction industry by studying the major components of the innovation process such as the major drivers of innovation, barriers and obstacles that prevent innovation, the enablers that motivate innovation, the practices of innovation, and the benefits of innovation both at project and company level. This paper is based on the data collected by means of structured questionnaires and analyzed throughsurvey analysis. The survey, which consisted of 46 factors involved in the innovation process, was distributed to 121 different participants, and the collected data were analyzed by the relative importance index (RII), as well as the analytical hierarchy process (AHP). The RII rankings feed the AHP analysis as the first step to rank the factors. Later, the factors are ranked according to the AHP analysis. Based on these rankings, recommendations are made to contractors, consultants, project management professionals, owners and suppliers.
\end{abstract}

Keywords: innovation, analytical hierarchy process, innovation management, innovational planning, relative importance index, construction.

JEL Classification: C83, L74, O22.

\section{Introduction}

Construction engineers play a major role in the built environment by designing construction facilities and field operations and supplying materials (Tatum, 2018). It is one of the most sophisticated industries that require huge effort due to various challenging factors regarding to the planning and studying of projects. These factors would include the vision, financial stability, logistics and location of projects, transportation, availability of resources, stability and security of the country, time constraints, and finally construction specifications and standards. The factors that contribute most to the innovation of the construction industry are suppliers and growth of business (Barata \& Fontainha, 2017). Effective innovation through these factors would lead to better project performance.

${ }^{\star}$ Corresponding author. E-mail: mgunduz@qu.edu.qa

This is an Open Access article distributed under the terms of the Creative Commons Attribution License (http://creativecommons. org/licenses/by/4.0/), which permits unrestricted use, distribution, and reproduction in any medium, provided the original author and source are credited. 
Keeping this in view, the concept of innovational practices in the construction sector is introduced under the category of construction management. This study applies the concept of innovation management in the construction industry by studying the major components of the innovation process that include the major drivers of innovation, barriers and obstacles that prevent innovation, the enablers that motivate innovation, the practices of innovation, and the benefits of innovation on project and firm level. This paper aims to analyze the influence of the innovation process on the project performance in the construction industry.

To achieve the aforementioned aim goals, the factors that affect the innovation process were studied and analyzed after measuring them through the AHP (Analytical Hierarchy Process) method, The contribution of each construction organization (contractor, consultant, project management, and owner) was determined. The weight of each organizational involvement was measured based on the ranking of innovation factors for that particular organization. This study is unique in the sense that it analyzes the factors that affect the innovation performance (driver factors, enablers factors, barriers factors, input factors) with a powerful multi-criteria decision making tool. It also quantifies the impact of each innovation factor for different organization types. Finally, a unique solution is proposed in order to enhance the innovation process in the construction industry.

\section{Literature review}

In this section, Innovation factors are reviewed by reporting on the academic literature related to the components and management of innovation.

Certain previous studies tried to identify the factors or components of the innovation process in the construction industry. In this respect, a total of 38 factors associated with innovation were identified and grouped under six components, namely the drivers, barriers, enablers, inputs, project-level benefits, and firm-level benefits by Ozorhon, Oral, and Demirkesen (2016). Liu, Skibniewski, and Wang (2016) identified 20 critical success factors (CSFs) of innovation in China's construction projects through literature review, a case study and expert interviews. Integrated Structural Modelling (ISM) and MICMAC (Impact Matrix Cross-reference Multiplication Applied to a Classification) analysis were used to hierarchically structure CSFs as well as to analyse their inter-relationships. Ozorhon (2013) investigated the innovation process in construction projects. and proposed a framework to explore various components of innovation, including the drivers, inputs, enablers, barriers, innovative activities, benefits, and impacts. Ozorhon's framework was employed in four case studies concerning some award-winning projects in the UK. Horta, Camanho, and Moreira Da Costa (2012) examined the trends in the performance of the Portuguese construction industry, and identified the factors that promoted excellence and innovation in the sector. They concluded that company performance was strongly affected by the national economic context, and also that small specialized companies and large contractors tended to achieve the best performance levels. The outcome of Brchner and Olofsson (2012)'s work is a set of measurements that can be applied to the selection of any type of proposed new construction or repair technology innovation according to their potential impact on industry productivity. Gambatese and Hallowell (2011) indicated that there were numerous statistically significant 
motivating factors for investment in the initial development of successful technical innovation, as well as barriers and enablers to efficient diffusion and innovation of construction projects. Barata and Fontainha (2017) identified the determinants of process and product innovation in a traditional, low-tech sector, supported in micro, small and medium-sized enterprises (SMEs), namely the European Construction Sector.

Some past literature developed models to understand the innovation process. Bento and Fontes (2015) analyzed the construction process of a new innovation system based on wind energy in a "follower" context. The technological innovation systems framework was used to analyze the process of technology diffusion as well as the emergence of a new wind sector in Portugal. Murphy, Perera, and Heaney (2015) investigated whether the constructs could be integrated to develop a practical tool for use by project stakeholders who were desirous to generate innovation. Process modelling, statistical analysis and failure mode and effect analysis were used to align the constructs into a test model (TM). Villarreal and Calvo (2015) discussed the use of the Triple Helix model as framework, within a new approach that could be transferred to other countries. Loosemore (2015) developed a theoretical model of innovation in construction on the basis of fifth-generation innovation research. Shibeika and Harty (2015) investigated how digital innovations diffused across complex firms through the Diffusion of innovations theory. Pellicer, Yepes, Correa, and Alarcón (2014) conducted their study over a five-year period, and generated a set of 18 propositions as refletions of an explanatory model of innovation management. An event study model was used by Kajander, Sivunen, Vimpari, Pulkka, and Junnila (2012) to analyse the sustainability of innovation announcements and financial information of large construction sector companies in a number of countries. The diffusion patterns of the identified safety innovations were explored by Esmaeili and Hallowell (2012) through four common innovation diffusion models: the internal, external, Bass, and Gompetz. Yu, Cheng, Wu, and Lou (2012) presented a self-evolutionary approach to assist the automated innovation of construction technologies. The proposed approach integrated a text mining technique, patent analysis, and a Genetic Algorithm (GA) to form a prototype automated radical technology innovation model. Gopalakrishnan and Damanpour (1994) addressed the debate over the occurrence and the applicability of unitary sequence and multiple sequence patterns in the innovation process in organizations. Mir, Casadesús, and Petnji (2016), whose study was an unprecedented contribution to innovation management literature, provided a novel analysis concerning the impact of a Standardized Innovation Management System (SIMS) on company innovation capability, innovation performance, and corporate results. Bi, Huang, Wang (2016) analyzed the innovation performance of low-carbon technological innovation activities under the global value chain and the influencing factors by combing the global value chain framework and linear innovation process model. Zeng, Xie, and Tam (2010) demonstrated the use of a system for the evaluation and measurement of innovation capabilities for a science park. Šaparauskas and Turskis (2006) revealed a number of difficulties which emerged as a result of developing the indicator system for sustainability evaluation, and of searching for the required information about indicators while making mathematical calculations.

The authors also looked at other past literature about AHP and innovation from various points. For instance, X. Deng and Y. Deng (2019) focused on the credibility of information 
within the D-AHP method and studied its impact on the results of a MCDM problem. They took into consideration information about different credibilities including high, medium and low, respectively. Zhou, Hu, Deng, Chan, and Ishizaka (2018) proposed a new completion method for incomplete pairwise comparison matrix (iPCM) based on the decisionmaking and trial evaluation laboratory (DEMATEL) method. Nagano, Stefanovitz, and Vick (2014) analyzed the relations of various internal organizational elements and the influence of contextual factors on innovation management and their challenges. Saunila and Ukko (2014) contributed to the current understanding by presenting a construct for categorizing the intangible aspects of organizational innovation capability. Pérez-Cano (2013) studied the influence of four dimensions of knowledge (codifiability, observability, complexity and dependency) on two types of appropriation methods: secrecy and other alternative methods (constant incremental improvements, lead time, moving down the learning curve and control of complementary resources); and how the size of a firm modifies these relations. Irwin, Hoffman, and Lamont (1998) examined the relationship between the acquisition of technological innovations and organizational performance using the framework of firm resourcebased theory. Chen and Deng (2018) proposed a modified method based on the analytical hierarchy process (AHP) and Dempster-Shafer evidence theory (D-S theory) for evaluating the impact of transport measures on city sustainability. Han and Deng (2018) proposed a model which combined fractal theory, Dempster-Shafer evidence theory and analytic hierarchy process (AHP) to classify objects with incomplete information. Bolívar-Ramos, GarcíaMorales, and García-Sánchez (2012) analyzed how top management support of technology influenced the generation of technological skills, technological distinctive competencies and organizational learning. Kimmel, Toohey, and Delborne (2016) paper investigated the features of the technology assessment and adoption processes in the U.S. public highway construction industry that both facilitated and hindered the relavant innovation. Scaringella and Burtschell (2017) investigated the collaboration between an Iranian and a French company in a joint venture that was aimed at developing radical innovation in the construction sector. Demaid and Quintas (2006) discussed a fundamental tension between understanding knowledge creation and use, and the drive to capture processes in formal documents and systems. Miozzo, Desyllas, Lee, and Miles (2016) found a significant positive correlation between the importance of innovation collaboration and the importance of formal appropriability mechanisms. Hervas-Oliver, Sempere-Ripoll, Boronat-Moll, and Rojas (2015) analyzed how management (organizational and marketing) innovations influenced non-R\&D technological innovators' performance. Similarly, the implementation of an innovation management system was analysed in a Spanish construction firm of medium size for 9 years by Yepes, Pellicer, Alarcón, and Correa (2016). Ozorhon, Abbott, and Aouad (2014) investigated the collaboration between an Iranian and a French company in a joint venture that was aimed at developing radical innovation in the construction sector. Chan, Liu, and Fellows (2014) investigated the effect of leadership on the innovation climate in construction firms by using the innovation climate as a proxy for organizational innovation.

The literature review helped identify the innovation factors that affected project success. These factors were then categorized into seven groups as benefits, innovation drivers, innovation barriers, innovation input factors, innovation enablers, models of innovation, 
innovation output namely. The factors that were associated with each of these seven groups were also identified. Moreover, the study categorized the data according to different types of organizations. The contribution of this study could be summarized as analyzing the innovation factors in the construction industry by taking into account the organization types separately with the help of AHP. In this respect, this study capturedthe effect of organization type on construction innovation.

Reviewing past literature on the factors of the innovation process was the first step in the research methodology. To this end, 46 different innovation factors were identified from the literature. These 46 factors were then categorized in seven groups. A list of the factors and their corresponding category can be seen in Table 1. A survey was also developed based on a 9-point Likert's scale ( 1 = lowest impact, 9 = highest impact). The surveyconsisted of two sections, namely the impact and general information sections. The general information section consisted of five questions to get an overview about the respondents; and this overview was used for categorization purposes, and also for studying the involvement of construction organizations in the innovation process. The data from 121 respondents were collected through a web-survey link and hard copies. The collected data were thenanalyzed by means of the Relative Importance Index (RII) and Analytical Hierarchy Process (AHP) to get an overview about the factors concerning the innovation process and their relative weights with respect to each other as well as with respect to the construction organization involvement.

Table 1. 46 Innovation factors

\begin{tabular}{|c|c|}
\hline Categories & Factors \\
\hline Organizations benefits & $\begin{array}{l}\text { Cost saving } \\
\text { Time saving } \\
\text { Quality improvement } \\
\text { Technology improvement } \\
\text { Construction safety improvement } \\
\text { Market improvement }\end{array}$ \\
\hline Innovation Drivers & $\begin{array}{l}\text { Client requirement } \\
\text { Competition level } \\
\text { Project performance improvement } \\
\text { Regulation and legislation } \\
\text { Knowledge exchange } \\
\text { Design trends } \\
\text { Environment and sustainability }\end{array}$ \\
\hline Innovation Barriers & $\begin{array}{l}\text { Lack of financial resources } \\
\text { Unsupportive organizational culture } \\
\text { Temporary nature of projects } \\
\text { Unavailability of materials } \\
\text { Lack of experienced and qualified staff } \\
\text { Lack of clear benefits } \\
\text { Time constraint }\end{array}$ \\
\hline Innovation Input factors & $\begin{array}{l}\text { Capital } \\
\text { Investment in R\&D } \\
\text { Internal knowledge management } \\
\text { External knowledge management } \\
\text { Consultancy } \\
\text { Innovation team }\end{array}$ \\
\hline
\end{tabular}


End of Table 1

\begin{tabular}{|c|c|}
\hline Categories & Factors \\
\hline Innovation Enablers & $\begin{array}{l}\text { Effective cooperation } \\
\text { Early contractor involvement } \\
\text { Leadership } \\
\text { Commitment } \\
\text { Reward schemes } \\
\text { Training policy }\end{array}$ \\
\hline Models of Innovation & $\begin{array}{l}\text { Modern methods of construction } \\
\text { Project management tools } \\
\text { Strategic Partnering } \\
\text { Supply chain partnership } \\
\text { Energy efficiency/ sustainability } \\
\text { Building Information Modelling (BIM) } \\
\text { Advanced materials } \\
\text { Lean construction } \\
\text { Automation } \\
\text { Marketing }\end{array}$ \\
\hline Innovation Output & $\begin{array}{l}\text { Shorter project duration } \\
\text { Increased productivity } \\
\text { Improved technical and managerial capability } \\
\text { Enhanced design trends }\end{array}$ \\
\hline
\end{tabular}

\section{Data characteristics}

Is the data were collected from construction professionals with different backgrounds worldwide. A total of 121 completed responses were received and analyzed. The data collected from professionals with different years of experience (most professionals in the construction industry have good experience). $16.5 \%$ of the respondents had less than 5 years of experience, $23.1 \%$ of the respondents had experience varying between 5 and 10 years $30.6 \%$ had $10-15$ years of experience, and $29.8 \%$ of the participants had experience of more than 15 years.

The construction organizations involved in this survey were contractors, consultants, owner's representatives, suppliers, and project management consultants. $43.8 \%$ of the participants were contractors, $12.4 \%$ were consultants, $14 \%$ were owner representatives, $17.4 \%$ were project managers, and finally $12.4 \%$ were suppliers.

Operation manager/general manager
Project manager

Construction manager

Site engineer

\section{$25.6 \%$}

$41.3 \%$

\section{$12.4 \%$}

$20.7 \%$

Figure 1. Designation percentages for respondents 
The designation of the respondents within their respected organizations are shown in Figure 1. It can be seen that project managers responded with the highest rate of $41.3 \%$, whereas construction managers ranked fourth by $12.4 \%$.

Due to the wide representation of the industry by location, organization and profession, the outcome of this research can be generalized to other parts of the world.

\section{Statistical data analysis methodology}

The 46 factors and their relevant categories were analyzed based on the RII and AHP. The AHP necessitated the RII in order to assign scores for each innovation factor.

\subsection{Relative Importance Index (RII)}

The relative importance index was used to measure the average impact level for the total number of participants in order to attain average values for the innovation process factors to initiate the process of AHP.

$$
\mathrm{RII}=\Sigma \mathrm{W} / \mathrm{A}^{\star} \mathrm{N},
$$

where: W - weight given to each factor by the respondents (1 to 9); A - the highest weight (in this case is 9); $\mathrm{N}$ - total number of respondents.

Then the factors were ranked based on the values from the RII, which varied from 1 to 9; the greater the value was, the higher the importance of each factor appeared to be.

\subsection{Analytical hierarchy process}

The AHP was first developed by Saaty (Saaty \&Vargas, 1979). The AHP implementation in the analysis stage of the project was based on prioritizing the innovation factors by collecting data about the importance level of each factor in the innovation process followed in the construction industry.

The AHP analysis method was used to test the factors of the innovation process which were taken as the decision criteria. There were 46 decision criteria, all related to the innovation process followed in the construction industry, all of the criteria were tested and evaluated to find out the importance level of each and every one of them with respect to their relative weight to different organizations (contractors, owners, project management, suppliers, and consultants). Ranking all factors thus proved useful in terms of determining which factors to consider and includemore in the construction innovation process. The last step involved synthesizing the results to determine the best alternative based on the results. The output of the AHP is the set of priorities for the alternatives.

\section{Data analysis}

\subsection{RII analysis}

The relative importance index is an intermediate step to initiate the AHP process, and it is one of the most powerful ranking methods. The major difference between the RII and AHP is that the AHP takes into account the correlation between the variables and categories as well. The results of RII, based on equation 1 for five different groups are presented in Table 2 . 
Table 2. RII scores for the innovation factors

\begin{tabular}{|c|c|c|c|c|c|}
\hline Factors & Contractor & Consultant & $\begin{array}{c}\text { Project } \\
\text { management }\end{array}$ & Owner & Supplier \\
\hline \multicolumn{6}{|c|}{ INNOVATION BENEFITS } \\
\hline 1 - Cost saving & 6.85 & 7.00 & 6.90 & 7.29 & 6.33 \\
\hline 2 - Time saving & 7.08 & 7.20 & 7.14 & 7.65 & 7.60 \\
\hline 3 - Quality improvement & 6.91 & 6.93 & 6.38 & 7.18 & 7.40 \\
\hline 4 - Technology improvement & 5.32 & 6.13 & 5.62 & 6.41 & 6.20 \\
\hline 5 - Construction safety improvement & 6.04 & 6.60 & 6.19 & 6.65 & 6.47 \\
\hline 6 - Market improvement & 5.55 & 6.33 & 5.81 & 6.18 & 5.87 \\
\hline \multicolumn{6}{|c|}{ DRIVERS FACTORS } \\
\hline 7 - Client requirement & 7.64 & 8.31 & 7.26 & 7.19 & 7.69 \\
\hline 8 - Competition level & 6.31 & 6.85 & 6.21 & 6.06 & 5.85 \\
\hline 9 - Project performance improvement & 7.04 & 7.15 & 7.16 & 6.81 & 6.85 \\
\hline 10 - Regulation and legislation & 5.91 & 6.54 & 6.00 & 6.06 & 3.69 \\
\hline 11 - Knowledge exchange & 5.31 & 6.46 & 5.84 & 5.81 & 5.08 \\
\hline 12 - Design trends & 6.20 & 7.31 & 6.26 & 6.56 & 7.00 \\
\hline 13 - Environment and sustainability & 6.13 & 7.08 & 5.84 & 6.25 & 6.31 \\
\hline \multicolumn{6}{|c|}{ BARRIERS FACTORS } \\
\hline 14 - Lack of financial resources & 7.53 & 8.38 & 7.37 & 7.56 & 7.31 \\
\hline $\begin{array}{l}15 \text { - Unsupportive organizational } \\
\text { culture }\end{array}$ & 5.98 & 7.38 & 7.05 & 6.56 & 5.62 \\
\hline 16 - Temporary nature of projects & 5.89 & 6.31 & 5.74 & 5.81 & 4.38 \\
\hline 17 - Unavailability of materials & 6.09 & 6.23 & 5.74 & 6.06 & 4.08 \\
\hline $\begin{array}{l}18 \text { - Lack of experienced and qualified } \\
\text { staff }\end{array}$ & 6.58 & 8.00 & 7.21 & 6.94 & 5.08 \\
\hline 19 - Lack of clear benefits & 6.02 & 6.85 & 5.95 & 6.13 & 3.85 \\
\hline 20 - Time constraint & 6.27 & 7.23 & 6.63 & 6.56 & 5.54 \\
\hline \multicolumn{6}{|c|}{ INPUT FACTORS } \\
\hline 21 - Capital & 7.47 & 7.92 & 7.47 & 7.13 & 7.00 \\
\hline 22 - Investment in R\&D & 5.96 & 6.08 & 6.47 & 6.31 & 5.77 \\
\hline 23 - Internal knowledge management & 6.33 & 6.31 & 6.26 & 6.00 & 5.38 \\
\hline 24 - External knowledge management & 6.09 & 6.54 & 6.05 & 6.06 & 5.77 \\
\hline 25 - Consultancy & 6.49 & 7.31 & 6.00 & 6.00 & 5.00 \\
\hline 26 - Innovation team & 6.84 & 7.23 & 7.26 & 6.69 & 7.77 \\
\hline \multicolumn{6}{|c|}{ ENABLERS FACTORS } \\
\hline 27 - Effective cooperation & 7.40 & 6.69 & 7.42 & 6.88 & 6.77 \\
\hline 28 - Early contractor involvement & 6.33 & 6.31 & 6.47 & 6.38 & 5.69 \\
\hline 29 - Leadership & 7.73 & 7.92 & 7.95 & 7.44 & 7.77 \\
\hline $30-$ Commitment & 7.09 & 7.54 & 7.53 & 6.81 & 6.23 \\
\hline 31 - Reward schemes & 6.24 & 6.46 & 6.68 & 6.13 & 6.00 \\
\hline
\end{tabular}


End of Table 2

\begin{tabular}{|c|c|c|c|c|c|}
\hline Factors & Contractor & Consultant & $\begin{array}{c}\text { Project } \\
\text { management }\end{array}$ & Owner & Supplier \\
\hline 32 - Training policy & 6.36 & 6.62 & 7.00 & 6.88 & 7.31 \\
\hline \multicolumn{6}{|c|}{ INNOVATION MODELS } \\
\hline 33 - Modern methods of construction & 7.69 & 7.00 & 7.82 & 7.60 & 7.77 \\
\hline 34 - Project management tools & 5.67 & 7.17 & 7.06 & 7.33 & 5.38 \\
\hline 35 - Strategic Partnering & 5.49 & 7.00 & 6.82 & 6.60 & 5.62 \\
\hline 36 - Supply chain partnership & 5.31 & 5.67 & 6.47 & 6.40 & 5.77 \\
\hline 37 - Energy efficiency/ sustainability & 5.44 & 6.92 & 6.59 & 6.20 & 6.08 \\
\hline $\begin{array}{l}38 \text { - Building Information Modelling } \\
\text { (BIM) }\end{array}$ & 6.29 & 7.42 & 7.12 & 6.73 & 6.92 \\
\hline 39 - Advanced materials & 6.76 & 6.67 & 7.12 & 6.93 & 7.69 \\
\hline 40 - Lean construction & 6.44 & 5.92 & 6.65 & 5.87 & 5.54 \\
\hline 41 - Automation & 6.98 & 6.42 & 7.35 & 6.60 & 6.92 \\
\hline 42 - Marketing & 5.40 & 6.08 & 6.41 & 6.47 & 5.62 \\
\hline \multicolumn{6}{|c|}{ OUTPUT FACTORS } \\
\hline 43 - Shorter project duration & 7.56 & 6.17 & 7.65 & 7.47 & 7.54 \\
\hline 44 - Increased productivity & 7.73 & 7.25 & 7.71 & 7.27 & 8.00 \\
\hline $\begin{array}{l}45 \text { - Improved technical and } \\
\text { managerial capability }\end{array}$ & 6.24 & 7.25 & 6.47 & 7.07 & 6.23 \\
\hline 46 - Enhanced design trends & 6.44 & 6.67 & 6.88 & 7.13 & 6.08 \\
\hline
\end{tabular}

\subsection{AHP analysis}

Analysis results of the collected data are discussed using the AHP method. The output of AHP is the set of priorities of the alternatives. The formulation of AHP can be shown by the equation below:

$$
\mathrm{S}_{\mathrm{i}}=\sum\left(\mathrm{g}_{\mathrm{ij}} \times \mathrm{W}_{\mathrm{j}}\right),
$$

where: $\mathrm{W}_{\mathrm{j}}$ - a weight between 0 and 1 was assigned to criterion $\mathrm{j} ; 1.00$ Important, 0 Unimportant; sum of total weighs equals one. This value was calculated based on the rankings of the respondents; $g_{i j}$ - a grade between 0 and 100 indicaties how well alternative $i$ satisfies criteria j; 100 indicates high satisfaction, 0 low satisfaction. i corresponds to the number of categories and range from 1 to 7 ; and $j$ represents the number of factors in that specific category.

The equation takes into account the rating for benefits $\left(\mathrm{g}_{\mathrm{ij}}\right)$ and organizations $\left(\mathrm{W}_{\mathrm{j}}\right)$. Each decision alternative is graded in terms of how well it satisfies the criterion accordingly.

The first step of the AHP was to score the arranged factors based on the RII rankings and construct different matrices for each innovation category for each construction organization. The RII rankings were first fed into the AHP analysis to determine the weight of each of the 7 groups. There were 5 different construction organizations (contractor, consultant, project management, owner, and supplier) with 7 different categories (as shown in Table 1). Firstly, 
the weight of construction organizations and their level of involvement in the innovation process were calculated based on the assumption that the higher an innovation factor scored for a given organization, the higher the involvement of that organization was in the innovation. This helped determine the $\mathrm{W}_{\mathrm{j}}$ value in Equation 2. The construction organizations who rated the factors of innovation process with high values were more familiar with and involved in the innovation process due to their better understanding of the importance of the innovation in construction. An average rating (AR) was calculated for the values of each of the 46 factors for each organization as follows:

$$
\left.\mathrm{AR}_{\mathrm{i}}=\left(\sum \mathrm{RII}_{\mathrm{ij}}\right)\right) / \mathrm{N},
$$

where $\mathrm{i}=1,2, \ldots, 5, \mathrm{j}=1,2, \ldots, 46 . \mathrm{RII}_{\mathrm{ij}}$ is the corresponding RII scores of the $\mathrm{jth}$ factor for the ith organization in Table $2 . \mathrm{N}$ is equal to 46.

These data were gathered through the RII analysis. After determination of the average ratings, an AHP pair wise comparison matrix was developed for the construction organization as shown in Equation 4 below. This lead to the gij value in Equation 2. The pair wise comparison matrix is a $\mathrm{n} \times \mathrm{n}$ real matrix, where $\mathrm{n}$ is the number of evaluation criteria considered.

$$
\mathrm{A}_{\mathrm{ij}} \cdot \mathrm{a}_{\mathrm{ji}}=1 .
$$

Obviously, $\mathrm{a}_{\mathrm{ii}}=1$ for all $\mathrm{i}$.

Each entry ajk of the matrix represents the importance of the jth criterion relative to the $\mathrm{kth}$ criterion. If $\mathrm{a}_{\mathrm{ij}}>1$, then the ith criterion is more important than the jth criterion, while if aij $<1$, then the ith criterion is less important than the jth criterion.

The scale to develop comparison matrix and the pairwise comparison matrix for each organization according to the AHP analysis are shown in Table 3 and Table 4 respectively.

Table 3. Scale to develop pairwise comparison matrix

\begin{tabular}{|c|l|}
\hline SCALE & \multicolumn{1}{|c|}{ Degree of preference } \\
\hline 1 & Equal Importance \\
\hline 3 & Moderate importance of one factor over another \\
\hline 5 & Strong or essential importance \\
\hline 7 & Very strong importance \\
\hline 9 & Extreme importance \\
\hline $2,4,6,8$ & Values for inverse comparison \\
\hline
\end{tabular}

Table 4. Pairwise comparison matrix for construction organizations

\begin{tabular}{|l|c|c|c|c|c|}
\hline & Contractor & Consultant & Project management & Owner & Supplier \\
\hline Contractor & 1.0 & 0.143 & 0.200 & 0.333 & 3.0 \\
\hline Consultant & 7.0 & 1.0 & 3.0 & 5.0 & 9.0 \\
\hline Project management & 5.0 & 0.333 & 1.0 & 3.0 & 7.0 \\
\hline Owner & 3.0 & 0.200 & 0.333 & 1.0 & 5.0 \\
\hline Supplier & 0.333 & 0.111 & 0.143 & 0.200 & 1.0 \\
\hline
\end{tabular}


The next step after developing the pair wise comparison matrix was to normalize each column in the developed matrix, and then the average of each row was computed to end up with the weight percentage of each organization's involvement in the innovation process. In this way, the Wj value was calculated in Equation 2 as displayed in Figure 2, which summarizes the weight of involvement of each organization in the innovation process.

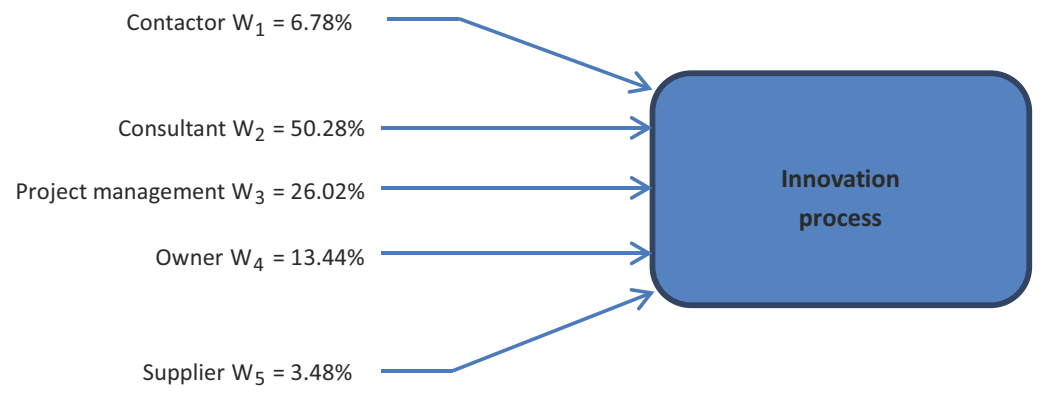

Figure 2. Weight of each construction organization according to AHP

For each category and organization, a matrix was developed for ranking purposes to determine the $\mathrm{g}_{\mathrm{ij}}$ value in Equation 2. A total of 35 matrices were constructed to evaluate the 46 factors under investigation. During these analyses, the scores of the factors were normalized to percentages. Table 5 shows a sample calculation of contractor vs. innovation benefits as one of the pairwise comparison matrices.

Table 5. Pairwise comparison matrix for contractor vs. innovation benefits

\begin{tabular}{|l|c|c|c|c|c|c|}
\hline \multicolumn{7}{|c|}{ Contractor } \\
\hline & $\begin{array}{c}\text { Cost } \\
\text { saving }\end{array}$ & $\begin{array}{c}\text { Time } \\
\text { saving }\end{array}$ & $\begin{array}{c}\text { Quality } \\
\text { improvement }\end{array}$ & $\begin{array}{c}\text { Technology } \\
\text { improvement }\end{array}$ & $\begin{array}{c}\text { Construction } \\
\text { safety }\end{array}$ & $\begin{array}{c}\text { Market } \\
\text { improvement }\end{array}$ \\
\hline Cost saving & 1 & 0.333 & 0.5 & 5 & 2 & 3 \\
\hline Time saving & 3 & 1 & 2 & 9 & 5 & 7 \\
\hline Quality improvement & 2 & 0.50 & 1 & 7 & 3 & 5 \\
\hline $\begin{array}{l}\text { Technology } \\
\text { improvement }\end{array}$ & 0.2 & 0.111 & 0.143 & 1 & 0.333 & 0.5 \\
\hline Construction safety & 0.5 & 0.2 & 0.333 & 3 & 1 & 2 \\
\hline Market improvement & 0.333 & 0.143 & 0.2 & 2 & 0.5 & 1 \\
\hline
\end{tabular}

The last step in the AHP analysis was to calculate a Consistency Ratio (CR) to measure how consistent the judgments were in regard to large samples of purely random judgments. If the CR was less than 0.1, the consistency level was acceptable (Hadidi \& Khater, 2015). Appendix A shows the consistency analysis. The derived priorities in Tables 6 and 7 are consistent. 


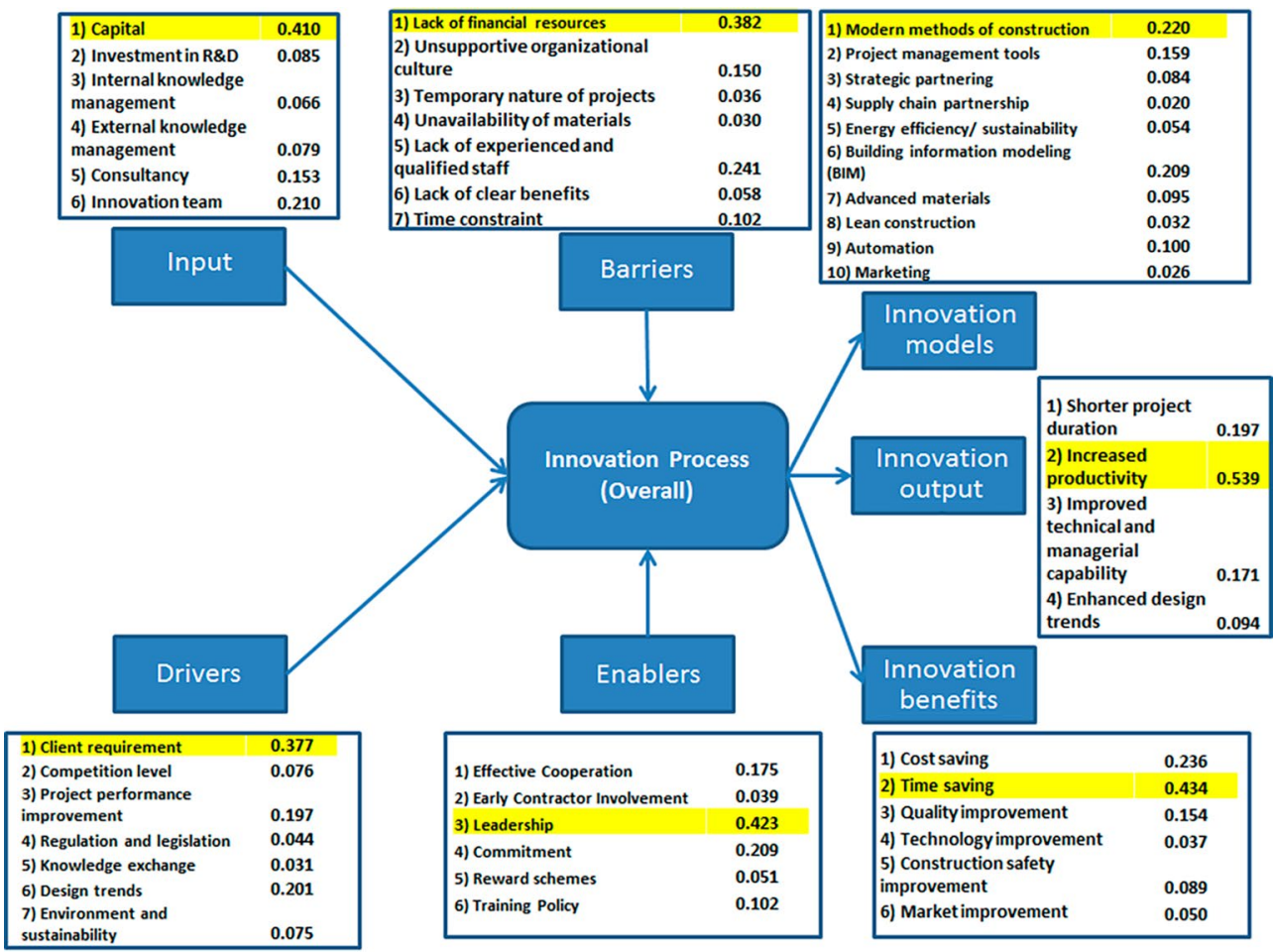

Figure 3. Overall AHP Ranking for the innovation factors

The last step in the AHP method was to multiply each factor in each organization by its organization weight as extracted from the total rating average of all innovation factors for each construction organization. Finally, a summation of the scores of each factor and multiplied to their relative organization weight gave the ranking of each factor. The overall ranking results for the innovation factors are summarized in Figure 3. The highest factor scores are highlighted in the figure.

\section{Discussion of results}

This paper studied the innovation process for a variety of construction organization types. The purpose of studying the innovation process for different construction organizations was to have real and detailed understanding of the innovation process in the construction industry. One of the objectives was to recognize which type of construction organization should be most concerned about enhancing the innovation process. Analysis of the collected data revealed that consultants were the most involved construction organization type in the innovation process and it had more weightof involvement (50.2\%); the next most effective construction organization type in the innovation process was project management organization with a score of $26.02 \%$; it was followed by owner representative with $13.44 \%$, and then by contractor with $6.78 \%$, and finally by supplier with $3.48 \%$. 
The next objective in this paper was to rank of the innovation factors for each construction organization. The analysis results for each construction organization gave the summary of the innovation factors as ranking values for different construction organizations. Figure 3 shows the overall ranking for the innovation factors according to the different impact level of each construction organization in the innovation process. Based on these results, it was concluded that the most important input factor to initiate the innovation process was providing enough capital and funding for the innovation process. Public authorities are huge clients and the innovation process could be easily applied for huge scale projects under the necessary public organizations. The required fund for innovation will boost the project to high performance. Moreover, it was noticed that the major reason to initiate the innovation concept was found to be the client requirement rather than improving the construction process and competitive dimension in the construction market. The clients however should take the lead to start the innovation process as early as possible in the projects. The major obstacle to initiate the innovation process is the shortage of financial support and resources to motivate and initiate the innovation practices. Leadership, as one of the most important factors in this study, should be carefully applied in the innovation process. Finally, as per client requirements, it was found that having new and modern methods of construction was the best innovation approach to achieve the organizational goals of increasing the productivity and hence finishing the projects earlier to save time. Engineering management in the construction industry is not a new topic to be studied and discussed, and it has been on the stage since the start of construction industry. However, the global market requirements and the worldwide competition need unique methods to manage the construction projects. Therefore, the topic of innovation in the construction industry needs to be considered by all relevant parties.

\section{Recommendation to industry professionals}

\section{Contractor}

Contractor involvement was found to be only $6.78 \%$, which was relatively low compared to the involvement of other organizations in the innovation process. Therefore, contractors need more innovation and automation due to market competition. However, their involvement level is low. Based on the findings, contractors are recommended to invest more on external knowledge management as well as research and development management to initiate the concept of innovation in their projects in order to be successful in complex projects.

\section{Consultant}

The Consultant is the construction organization that cares about finding solutions, solving technical and operational issues. The involvement of consultants in innovation was determined to be significantly high er than that of other organizations with a percentage of $50.28 \%$. This was interpreted as a result of their involvement in studying and reviewing the modern methods of construction and advanced materials used in construction. Consultants should be involved in innovation management to monitor and control the innovation process. Besides, consultants should be able to provide up-to-date knowledge to related parties to increase productivity levels through innovation. 


\section{Project management}

The role of project managers in construction projects is mainly to manage all project stakeholders. They are mainly concerned about the progress and budget of the project. According to the findings of this study, project management involvement in innovation has a percentage of $26.02 \%$. The project management should consider innovation process in developing effective coordination between all project parties. The project management should also set up the necessary platforms to boost innovational practices.

\section{Owner}

Owner involvement in innovation is low because owners are not responsible about the method of project execution techniques or project technical issues. Owners should involve in the innovation project because as one of the major driver factors that would initiate the innovation process. Having knowledge about innovation from other projects and providing financial support give the owners the opportunity to successfully achieve complex project objectives.

\section{Supplier}

Suppliers have the lowest involvement percentage in innovation process with a score of $3.48 \%$. Their role is not flexible and they depend on production quantities and purchase orders from the clients. They focus less on problem solving or new invention. Suppliers should care more about the department of research and development to continuously monitor the market alternatives and improve their product. Suppliers should involve in innovation management to develop and recommend technical solutions and budget alternatives. Suppliers should also provide up-to-date practices to relevant parties through effective communication with all relevant parties.

\section{Conclusions and future work}

Engineering management in the construction industry is utilized in almost all construction projects. However, the global market and the worldwide competition require innovative and unique methods to manage the construction projects. Therefore, the topic of innovation in construction industry is required to be studied in detail in order to fulfill the competitive dimensions of global market. This paper applied the concept of innovation management in the construction industry by studying the major components of the innovation process, which included the major drivers to innovation, barriers and obstacles that prevent innovation, the enablers that motivate innovation, the practices of innovation, and the benefits of innovation. The collected data were analyzed using RII and AHP methods. The results from the RII method were used as a base to rank the factors with the AHP method.

Based on the findings, it was concluded that the most important input factor to initiate the innovation process was providing a sufficient amount of capital and funding the innovation process. Moreover, it was noticed that the major reason to initiate the innovation concept was the client requirement rather than improving the construction process or competitive dimension in the construction market. Moreover, leadership was found to be one of the most significant factors that should be carefully used in the innovation process. 
The major obstacle to initiate the innovation process as shown by data analysis is the shortage of financial support and resources to motivate and initiate the innovation practices.

One limitation for the paper is that it did not consider the correlation between the variables. Possible correlation between variables can be studied by other models in future studies. Moreover, the significant factors determined by this study can be a studied separately in a case study to further investigate their impact on projects.

\section{References}

Barata, J. M., \& Fontainha, E. (2017). Determinants of innovation in European construction firms. Technological and Economic Development of Economy, 23(6), 915-936.

https://doi.org/10.3846/20294913.2016.1212437

Bento, N., \& Fontes, M. (2015). The construction of a new technological innovation system in a follower country: Wind energy in Portugal. Technological Forecasting and Social Change, 99, 197-210. https://doi.org/10.1016/j.techfore.2015.06.037

Bi, K., Huang, P., \& Wang, X. (2016). Innovation performance and influencing factors of low-carbon technological innovation under the global value chain: A case of Chinese manufacturing industry. Technological Forecasting and Social Change, 111(October 2016), 275-284. https://doi.org/10.1016/j.techfore.2016.07.024

Bolívar-Ramos, M. T., García-Morales, V. J., \& García-Sánchez, E. (2012) Technological distinctive competencies and organizational learning: Effects on organizational innovation to improve firm performance. Journal of Engineering and Technology Management - JET-M, 29(3), 331-337. https://doi.org/10.1016/j.jengtecman.2012.03.006

Brchner, J., Olofsson, T. (2012). Construction productivity measures for innovation projects. Journal of Construction Engineering and Management, 138(5), 670-677. https://doi.org/10.1061/(ASCE)CO.1943-7862.0000481

Chan, I. Y. S., Liu, A. M. M., \& Fellows, R. (2014). Role of leadership in fostering an innovation climate in construction firms. Journal of Management in Engineering, 30(6). https://doi.org/10.1061/(ASCE)ME.1943-5479.0000271

Chen, L., \& Deng, X. (2018). A modified method for evaluating sustainable transport solutions based on AHP and Dempster-Shafer evidence theory. Applied Sciences (Switzerland), 8(4), 563. https://doi.org/10.3390/app8040563

Demaid, A., \& Quintas, P. (2006). Knowledge across cultures in the construction industry: Sustainability, innovation and design. Technovation, 26(5-6), 603-610. https://doi.org/10.1016/j.technovation.2005.06.003

Deng, X., \& Deng, Y. (2019). D-AHP method with different credibility of information. Soft Computing, 23(2), 683-691. https://doi.org/10.1007/s00500-017-2993-9

Esmaeili, B., \& Hallowell, M. R. (2012). Diffusion of safety innovations in the construction industry. Journal of Construction Engineering and Management, 138(8), 955-963. https://doi.org/10.1061/(ASCE)CO.1943-7862.0000499

Gambatese, J. A., \& Hallowell, M. (2011). Factors that influence the development and diffusion of technical innovations in the construction industry. Construction Management and Economics, 29(5), 507-517. https://doi.org/10.1080/01446193.2011.570355

Gopalakrishnan, S., \& Damanpour, F. (1994). Patterns of generation and adoption of innovation in organizations: Contingency models of innovation attributes. Journal of Engineering and Technology Management, 11(2), 95-116. https://doi.org/10.1016/0923-4748(94)90001-9 
Han, Y., \& Deng, Y. (2018). An evidential fractal analytic hierarchy process target recognition method. Defence Science Journal, 68(4), 367-373. https://doi.org/10.14429/dsj.68.11737

Hadidi, L. A., \& Khater, M. A. (2015). Loss prevention in turnaround maintenance projects by selecting contractors based on safety criteria using the analytic hierarchy process (AHP). Journal of Loss Prevention in the Process Industries, 34, 115-126. https://doi.org/10.1016/j.jlp.2015.01.028

Hervas-Oliver, J.-L., Sempere-Ripoll, F., Boronat-Moll, C., \& Rojas, R. (2015). Technological innovation without R\&D: unfolding the extra gains of management innovations on technological performance. Technology Analysis and Strategic Management, 27(1), 19-38.

https://doi.org/10.1080/09537325.2014.944147

Horta, I. M., Camanho, A. S., \& Moreira Da Costa, J. (2012). Performance assessment of construction companies: A study of factors promoting financial soundness and innovation in the industry. International Journal of Production Economics, 137(1), 84-93. https://doi.org/10.1016/j.ijpe.2012.01.015

Irwin, J. G., Hoffman, J. J., \& Lamont, B. T. (1998). The effect of the acquisition of technological innovations on organizational performance: A resource-based view. Journal of Engineering and Technology Management - JET-M, 15(1), 25-54. https://doi.org/10.1016/S0923-4748(97)00028-3

Kajander, J.-K., Sivunen, M., Vimpari, J., Pulkka, L., \& Junnila, S. (2012). Market value of sustainability business innovations in the construction sector. Building Research and Information, 40(6), 665-678. https://doi.org/10.1080/09613218.2012.703893

Kimmel, S. C., Toohey, N. M., \& Delborne, J. A. (2016). Roadblocks to responsible innovation: Exploring technology assessment and adoption in U.S. public highway construction. Technology in Society, 44, 66-77. https://doi.org/10.1016/j.techsoc.2015.12.002

Liu, H., Skibniewski, M. J., \& Wang, M. (2016). Identification and hierarchical structure of critical success factors for innovation in construction projects: Chinese perspective. Journal of Civil Engineering and Management, 22(3), 401-416. https://doi.org/10.3846/13923730.2014.975739

Loosemore, M. (2015). Construction innovation: Fifth generation perspective. Journal of Management in Engineering, 31(6). https://doi.org/10.1061/(ASCE)ME.1943-5479.0000368

Miozzo, M., Desyllas, P., Lee, H.-F., \& Miles, I. (2016). Innovation collaboration and appropriability by knowledge-intensive business services firms. Research Policy, 45(7), 1337-1351. https://doi.org/10.1016/j.respol.2016.03.018

Mir, M., Casadesús, M., Petnji, L. H. (2016). The impact of standardized innovation management systems on innovation capability and business performance: An empirical study. Journal of Engineering and Technology Management - JET-M, 41, 26-44. https://doi.org/10.1016/j.jengtecman.2016.06.002

Murphy, M. E., Perera, S., \& Heaney, G. (2015). Innovation management model: a tool for sustained implementation of product innovation into construction projects. Construction Management and Economics, 33(3), 209-232. https://doi.org/10.1080/01446193.2015.1031684

Nagano, M. S., Stefanovitz, J. P., \& Vick, T. E. (2014). Innovation management processes, their internal organizational elements and contextual factors: An investigation in Brazil. Journal of Engineering and Technology Management - JET-M, 33, 63-92. https://doi.org/10.1016/j.jengtecman.2014.02.004

Ozorhon, B. (2013). Analysis of construction innovation process at project level. Journal of Management in Engineering, 29(4), 455-463. https://doi.org/10.1061/(ASCE)ME.1943-5479.0000157

Ozorhon, B., Abbott, C., \& Aouad, G. (2014). Integration and leadership as enablers of innovation in construction: Case study. Journal of Management in Engineering, 30(2), 256-263. https://doi.org/10.1061/(ASCE)ME.1943-5479.0000204

Ozorhon, B., Oral, K., \& Demirkesen, S. (2016). Investigating the components of innovation in construction projects. Journal of Management in Engineering, 32(3).

https://doi.org/10.1061/(ASCE)ME.1943-5479.0000419 
Pellicer, E., Yepes, V., Correa, C. L., \& Alarcón, L. F. (2014). Model for systematic innovation in construction companies [Modelo para la Innovación Sistemática en Empresas Constructoras]. Journal of Construction Engineering and Management, 140(4). https://doi.org/10.1061/(ASCE)CO.1943-7862.0000700

Pérez-Cano, C. (2013). Firm size and appropriability of the results of innovation. Journal of Engineering and Technology Management - JET-M, 30(3), 209-226. https://doi.org/10.1016/j.jengtecman.2013.03.002

Saaty, T. L., \& Vargas, L. G. (1979). Estimating technological coefficients by the analytic hierarchy process. Socio-Economic Planning Sciences, 13(6), 333-336. https://doi.org/10.1016/0038-0121(79)90015-6

Šaparauskas, J., \& Turskis, Z. (2006). Evaluation of construction sustainability by multiple criteria methods. Technological and Economic Development of Economy, 12(4), 321-326.

Saunila, M., \& Ukko, J. (2014). Intangible aspects of innovation capability in SMEs: Impacts of size and industry. Journal of Engineering and Technology Management - JET-M, 33, 32-46.

https://doi.org/10.1016/j.jengtecman.2014.02.002

Scaringella, L., \& Burtschell, F. (2017). The challenges of radical innovation in Iran: Knowledge transfer and absorptive capacity highlights - evidence from a joint venture in the construction sector. Technological Forecasting and Social Change, 122C, 151-169. https://doi.org/10.1016/j.techfore.2015.09.013

Shibeika, A., \& Harty, C. (2015). Diffusion of digital innovation in construction: a case study of a UK engineering firm. Construction Management and Economics, 33(5-6), 453-466. https://doi.org/10.1080/01446193.2015.1077982

Tatum, C. B. (2018). Construction engineering research: integration and innovation. Journal of Construction Engineering and Management, 144(3). https://doi.org/10.1061/(ASCE)CO.1943-7862.0001445

Villarreal, O., \& Calvo, N. (2015). From the Triple Helix model to the Global Open Innovation model: A case study based on international cooperation for innovation in Dominican Republic. Journal of Engineering and Technology Management - JET-M, 35, 71-92. https://doi.org/10.1016/j.jengtecman.2014.10.002

Yepes, V., Pellicer, E., Alarcón, L. F., \& Correa, C. L. (2016). Creative innovation in Spanish construction firms. Journal of Professional Issues in Engineering Education and Practice, 142(1). https://doi.org/10.1061/(ASCE)EI.1943-5541.0000251

Yu, W.-D., Cheng, S.-T., Wu, C.-M., \& Lou, H.-R. (2012). A self-evolutionary model for automated innovation of construction technologies. Automation in Construction, 27, 78-88. https://doi.org/10.1016/j.autcon.2012.04.018

Zeng, S., Xie, X., \& Tam, C. (2010). Evaluating innovation capabilities for science parks: A system model [Mokslo ir technologijų parkų inovacinio pajègumo vertinimas: Sistemos modelis]. Technological and Economic Development of Economy, 16(3), 397-413. https://doi.org/10.3846/tede.2010.25

Zhou, X., Hu, Y., Deng, Y., Chan, F. T. S., \& Ishizaka, A. (2018). A DEMATEL-based completion method for incomplete pairwise comparison matrix in AHP. Annals of Operations Research, 271(2), 1045-1066. https://doi.org/10.1007/s10479-018-2769-3 


\section{APPENDIX A}

Step 1: Calculate the nth root of products of matrix values

In Table 6, $\mathrm{n}=5$; Table 7, $\mathrm{n}=6$.

Let's take the first row in Table 6 as sample:

$\sqrt[5]{1 \times 0.143 \times 0.2 \times 0.333 \times 3}=0.491$.

Step 2: Calculate the summation of $n$th root of products of values

According to Table 6, the total sum is: $0.491+3.936+2.036+1+0.254=7.717$.

According to Table 7 , the total sum is: $1.307+3.516+2.172+1+0.284+0.765+0.460=$ 8.505 .

Step 3: Calculate the Eigenvector for each row of each matrix

Eigenvector $=\frac{\text { nth Root of Products of Value }}{\text { TOTAL SUMMATION }}$

Let's calculate the Eigenvector for contractor in Table 6:

Eigenvector $=\frac{0.491}{7.717}=0.064$.

Step 4: Calculate the matrix vector by multiplying the matrix of judgments by the Eigenvector, obtaining new vector.

The Calculation for the new vector as follow for Table 6:

Contractor vector: $1 \times 0.064+0.143 \times 0.510+0.2 \times 0.264+0.333 \times 0.130+3 \times 0.033=$ 0.332 ;

Consultant vector: $7 \times 0.064+1 \times 0.510+3 \times 0.264+5 \times 0.130+9 \times 0.033=2.697$;

Project management vector: $5 \times 0.064+0.333 \times 0.510+1 \times 0.264+3 \times 0.130+7 \times 0.033=$ 1.375 ;

Owner vector: $3 \times 0.064+0.2 \times 0.510+0.333 \times 0.264+1 \times 0.130+5 \times 0.033=0.677$;

Supplier vector: $0.333 \times 0.064+0.111 \times 0.510+0.143 \times 0.264+0.2 \times 0.130+1 \times 0.033=$ 0.175 ;

The new vector table (1): $(0.332,2.697,1.375,0.677,0.175)$;

The same for table (2), the new vector is: $(0.928,2.515,1.544,0.204,0.543,0.327)$.

Step 5: Divide the new vector result by its corresponding Eigenvector:

$\frac{0.332}{0.064}=5.217$, The result: $(5.217,5.287,5.211,5.225$, and 5.307$)$ this is for table 6 ;

The result: $(6.035,6.082,6.046,6.089,6.041$, and 6.047) this is for table 7 .

Step 6: Obtain the mean value $\lambda$ max:

$\lambda \max =\frac{5.217+5.287+5.211+5.225+5.307}{5}=5.250$ related to Table 6;

$\lambda \max =\frac{6.04+6.08+6.046+6.089+6.041+6.05}{6}=6.0575$ related to Table 7. 
Step 7: Calculate the Consistency index CI:

$$
\mathrm{CI}=\frac{\lambda \max -n}{n-1} \text {. }
$$

The consistency index values are:

$$
\begin{aligned}
& \mathrm{CI}=\frac{5.250-5}{5-1}=0.0625<0.1(\text { Acceptable }) \\
& \mathrm{CI}=\frac{6.0575-6}{6-1}=0.0115<0.1 \text { (Acceptable) }
\end{aligned}
$$

Table 6. Pairwise comparison matrix for contractor vs. innovation benefits

\begin{tabular}{|l|c|c|c|c|c|c|c|}
\hline & Contractor & Consultant & $\begin{array}{c}\text { Project } \\
\text { management }\end{array}$ & Owner & Supplier & $\begin{array}{c}\text { nth } \\
\text { Root of } \\
\text { Products } \\
\text { of Values }\end{array}$ & Eigenvector \\
\hline Contractor & 1 & 0.143 & 0.2 & 0.333 & 3 & 0.491 & 0.064 \\
\hline Consultant & 7 & 1 & 3 & 5 & 9 & 3.936 & 0.510 \\
\hline $\begin{array}{l}\text { Project } \\
\text { management }\end{array}$ & 5 & 0.333 & 1 & 3 & 7 & 2.036 & 0.264 \\
\hline Owner & 3 & 0.2 & 0.333 & 1 & 5 & 1.000 & 0.130 \\
\hline Supplier & 0.333 & 0.111 & 0.143 & 0.2 & 1 & 0.254 & 0.033 \\
\hline
\end{tabular}

Table 7. Pairwise comparison matrix for contractor vs. innovation benefits

\begin{tabular}{|l|c|c|c|c|c|c|c|c|}
\hline & $\begin{array}{c}\text { Cost } \\
\text { Saving }\end{array}$ & $\begin{array}{c}\text { Time } \\
\text { saving }\end{array}$ & $\begin{array}{c}\text { Quality } \\
\text { improve- } \\
\text { ment }\end{array}$ & $\begin{array}{c}\text { Technol- } \\
\text { ogy im- } \\
\text { provement }\end{array}$ & $\begin{array}{c}\text { Con- } \\
\text { struction } \\
\text { safety }\end{array}$ & $\begin{array}{c}\text { Market } \\
\text { improve- } \\
\text { ment }\end{array}$ & $\begin{array}{c}\text { nth Root } \\
\text { of Products } \\
\text { of Values }\end{array}$ & $\begin{array}{c}\text { Eigen- } \\
\text { vector }\end{array}$ \\
\hline Cost saving & 1 & 0.333 & 0.5 & 5 & 2 & 3 & 1.307 & 0.154 \\
\hline Time saving & 3 & 1 & 2 & 9 & 5 & 7 & 3.516 & 0.413 \\
\hline $\begin{array}{l}\text { Quality } \\
\text { improvement }\end{array}$ & 2 & 0.5 & 1 & 7 & 3 & 5 & 2.172 & 0.255 \\
\hline $\begin{array}{l}\text { Technology } \\
\text { improvement }\end{array}$ & 0.2 & 0.111 & 0.143 & 1 & 0.333 & 0.5 & 0.284 & 0.033 \\
\hline $\begin{array}{l}\text { Construction } \\
\text { safety }\end{array}$ & 0.5 & 0.2 & 0.333 & 3 & 1 & 2 & 0.765 & 0.090 \\
\hline $\begin{array}{l}\text { Market } \\
\text { improvement }\end{array}$ & 0.333 & 0.143 & 0.2 & 2 & 0.5 & 1 & 0.460 & 0.054 \\
\hline
\end{tabular}

